\title{
PENGEMBANGAN TES STANDAR BERASIS TEKNOLOGI INFORMASI DI JURUSAN PENDIDIKAN GEOGRAFI
}

\author{
Mona Adria Wirda, Nurmala Berutu, Riki Rahmad, Rohani \\ Jurusan Pendidikan Geografi Fakultas IImu Sosial Universitas Negeri Medan \\ Email: monaadria@unimed.ac.id
}

\begin{abstract}
ABSTRAK
Tujuan dari penelitian ini adalah untuk menyusun suatu naskah soal ujian komprehensif yang terstandar berbasis teknologi informasi. Tujuan tambahan dari penelitian ini ialah menganalisis respon mahasiswa mengenai tes standar berbasis teknologi informasi yang dikembangkan. Kelayakan naskah soal yang digunakan dalam tes standar berbasis TI meliputi kelayakan isi/materi dan kelayakan bahasa. Kelayakan isi atau materi ini meliputi kesesuaian dan kemutakhiran soal sesuai dengan kurikulum yang telah dirancang pada masing-masing KDBK. sedangkan kelayakan bahasa diukur dengan validasi bahasa yang digunakan sesuai dengan kriteria penulisan soal pilihan ganda yang benar. Persepsi mahasiswa terhadap penggunaan tes standar berbasis teknologi informasi ini dilakukan dengan menggunakan angket dengan skala likert. Hasil penilaian kelayakan tes standar menunjukan bahwa sebesar 80,75\% item soal tergolong valid (layak digunakan) dilihat dari aspek materi (isi), konstruksi soal, dan bahasa yang digunakan dalam kalimat soal maupun pilihan jawaban. Dari persentase tersebut dapat disimpulkan bahwa sebanyak 323 item soal sudah layak digunakan dalam tes standar. Namun, 19,25\% item soal tergolong invalid, ini artinya sebanyak 77 item soal yang tersebar di bidang teknik, pendidikan, fisik dan lingkungan, dan sosial, tidak layak untuk digunakan serta perlu perbaikan sebelum digunakan dalam tes standar ujian komprehensif di Jurusan Pendidikan Geografi. Dari indikator tampilan, pengoperasian, kemanfaatan dan materi, penilaian respon mahasiswa mengenai tes standar dapat disimpulkan bahwa secara umum respon mahasiswa terkategori sangat baik. Hal ini didapat dari persentase respon yang menunjukan angka 88,11\%. Artinya mahasiswa memberikan tanggapan yang positif mengenai implementasi aplikasi tes standar untuk ujian komprehensif.
\end{abstract}

Kata kunci: tes, tes standar, teknologi informasi

\section{PENDAHULUAN}

Lembaga pendidikan formal dan informal adalah salah satu tempat bagi peserta didik untuk menjadi manusia yang berkualitas yang memiliki bekal ilmu pengetahuan, keterampilan dan keahlian. Pendidikan merupakan faktor utama dalam pembentukkan pribadi manusia. Pendidikan sangat berperan dalam membentuk baik atau buruknya pribadi manusia menurut ukuran normatif. Menyadari akan hal tersebut, pemerintah sangat serius menangani bidang pendidikan, sebab dengan sistem pendidikan yang baik diharapkan muncul generasi penerus bangsa yang berkualitas dan mampu menyesuaikan diri untuk hidup bermasyarakat, berbangsa dan bernegara. Maka diperlukan seorang pendidik yang memberikan keteladanan, membangun kemauan, mengembangkan potensi dan kreativitas peserta didik. Hal tersebut dituangkan dalam proses pembelajaran.

Dalam rangka pembaharuan sistem pendidikan nasional telah ditetapkan visi, misi dan strategi pembangunan pendidikan nasional. Berdasarkan Peraturan Menteri Pendidikan Nasional Republik Indonesia Nomor 41 Tahun 2007 visi pendidikan nasional adalah terwujudnya sistem pendidikan sebagai pranata sosial yang kuat dan berwibawa untuk memberdayakan semua warga negara Indonesia berkembang menjadi manusia yang berkualitas sehingga mampu dan 
proaktif menjawab tantangan zaman yang selalu berubah. Terjadinya pembaharuan dalam dunia pendidikan merupakan respon terhadap perkembangan tuntutan global sebagai suatu upaya untuk mengadaptasikan sistem pendidikan yang mampu mengembangkan sumber daya manusia untuk memenuhi tuntutan zaman yang sedang berkembang. Melalui reformasi pendidikan, pendidikan harus berwawasan masa depan yang memberikan jaminan bagi perwujudan hak-hak azasi manusia untuk mengembangkan seluruh potensi dan prestasinya secara optimal guna kesejahteraan hidup di masa depan.

Kemajuan teknologi komunikasi khususnya komputer dan internet berdampak luas pada seluruh aspek kehidupan manusia. Kemajuan tersebut membawa manusia pada peradaban dan cara hidup yang baru. Kemajuan teknologi informasi ini juga berdampak pada dunia pendidikan. Munir (2012) berpendapat bahwa multimedia memiliki potensi untuk menawarkan kesempatan belajar dengan cara-cara yang baru. Penggunaan komputer dalam pembelajaran dapat melibatkan peserta didik secara aktif serta memberikan umpan balik terhadap proses pembelajaran.

Teknologi informasi memiliki manfaat yang begitu luas terhadap pencapaian tujuan pendidikan. Melalui teknologi informasi, guru dan siswa dapat mengoptimalkan potensi pendidikan yang ada sehingga tujuan pendidikan yang telah direncanakan bisa segera tercapai. Teknologi informasi memberikan kontribusi positif terhadap pembelajaran di sekolah dan supaya efektif diperlukan usaha sadar untuk saling bekerja sama antara kepala sekolah, guru, orang tua, siswa serta seluruh komponen pendukungnya termasuk infrastruktur sarana dan prasarana yang memadai (Hamid, 2016).

Teknologi informasi yang terus berkembang juga berdampak pada peran pendidikan sebagai modal pembangunan bangsa sehingga dituntut untuk semakin berperan aktif dalam meningkatkan dan mengembangkan kualitas sumber daya manusia. Perkembangan ilmu pengetahuan dan teknologi memiliki implikasi yang luas dalam kehidupan manusia sehingga manusia diharapkan perlu mendalami untuk mengambil manfaat secara optimal dan mereduksi implikasi negatif yang ada (Mukhtar, 2011). Teknologi informasi dan komunikasi berpotensi besar untuk dimanfaatkan dalam dunia pendidikan, setidaknya ada tujuh fungsi teknologi informasi dalam pendidikan yaitu sebagai sumber belajar, alat bantu belajar, fasilitas pembelajaran, standar kompetensi, sistem administrasi, dan pendukung keputusan sebagai infrastruktur.

Evaluasi merupakan bagian penting dalam siklus pendidikan. Hasil evaluasi sangat berpengaruh dalam pembuatan keputusan oleh pihak yang terkait seperti guru. Oleh karena itu, evaluasi merupakan salah satu kegiatan utama yang harus dilakukan oleh seorang guru dalam kegiatan pembelajaran. Dengan evaluasi, guru akan mengetahui perkembangan hasil belajar, intelegensi, bakat khusus, minat, hubungan sosial, sikap dan kepribadian siswa atau peserta didik serta secara umum dapat mengetahui berhasil dan tidaknya program pembelajaran.

Agar evaluasi dapat berhasil dengan baik diperlukan alat evaluasi yang tepat dan telah teruji dengan baik. Alat evaluasi harus juga dapat menghasilkan data yang diperlukan sesuai dengan tujuan evaluasi. Dalam pembelajaran, guru membutuhkan data yang berkaitan dengan perkembangan belajar siswa, oleh karena itu guru melakukan serangkaian pengukuran sesuai dengan jenis penilaian.

Evaluasi pada dasarnya memberikan pertimbangan atau harga nilai berdasarkan kriteria tertentu untuk mendapatkan informasi yang meyakinkan dan objektif, dimulai dari informasiinformasi kuantitatif dan kualitatif. Instrumennya (alatnya) harus cukup sahih, kukuh, praktis dan jujur. Terdapat tiga istilah dalam evaluasi, yaitu tes, pengukuran, dan penilaian (test, 
measurement, and assessment). Tes merupakan alat atau prosedur yang digunakan untuk mengetahui atau mengukur sesuatu dalam suasana, dengan cara dan aturan yang sudah ditentukan. Untuk keperluan evaluasi diperlukan alat evaluasi yang bermacam-macam, seperti kuesioner, tes, skala, format observasi, dan lain-lain.Dari sekian banyak alat evaluasi, secara umum dapat dikelompokkan menjadi dua, yakni alat tes dan nontes.Khusus untuk evaluasi hasil pembelajaran alat evaluasi yang paling banyak digunakan adalah tes.

Tes/ujian selalu dihubungkan
dengan cara pengukuran/penilaian terhadap seseorang tentang penguasaan materi tertentu. Hasil dari tes/ujian salah satunya digunakan untuk membuat keputusan lulus dan tidaknya atas materi tersebut. Hasil tes dianggap sebagai bukti yang valid dari individu,yang dapat digunakan, misalnya untuk kenaikan kelas, promosi jabatan, dan kelulusan. Sebelum adanya tes berbasis komputer, biasanya tes dilakukan secara tertulis dalam kertas (paper based test), tetapi seiring dengan perkembangan teknologi informasi tes tertulis mulai bergeser digantikan dengan tes berbasis komputer bahkan internet.

Dari berbagai bentuk jenis tes, ada suatu jenis tes yang instrumennya telah distandarisasi. Artinya, jenis tes tersebut telah diuji validitas dan relaibiliatsnya secara ketat serta telah diuji kelayakan penggunaannya secara praktis. Jenis tes ini disebut tes standar (standardized test).Salah satu pemanfaatan komputer dalam bidang penilaian pada dunia pendidikan dikenal dengan istilah CBT (Computer Based Testing). CBT diartikan serangkaian tes atau penilaian yang berbasis komputer baik itu melibatkan komputer standalone atau terhubung pada jaringan internet dan sebagian besar soal menggunakan bentuk pilihan ganda (Jimoh, 2012). Soal-soal yang disajikan dalam test tertulis dapat diubah menjadi test digital dan diakses siswa melalui komputer. CBT juga memungkinkan pengembangan soal yang mengintegrasikan film, suara dan animasi di dalamnya sehingga bentuk soal dapat didesain lebih kontekstual (Sudar, Yulianto, \& Wiyanto, 2014).

Pemberlakuan Kurikulum Berbaris Kompetensi untuk mahasiswa jurusan Pendidikan Geografi dimulai dari mahasiswa dengan NIM 2005 hingga seterusnya yang mensyaratkan adanya ujian akhir dari keseluruhan matakuliah dalam bentuk pilihan berganda. Sehubungan dengan itu, maka dibutuhkan materi tes yang berstandar berdasarkan KDBK sehingga kegiatan pembuatan materi tes standar jurusan Pendidikan Geografi ini perlu dilakukan.

Sesuai dengan tuntutan kurikulum bebasis kompetensi tersebut telak selesai dilaksanakan pembuatan materi test standar dan dilakukan uji test terhadap mahasiswa melalui komprehensif test sebanyak dua (2) kali pada anggaran 2008/2009. Berdasarkan pengalaman pada pelaksanaan komprehensif test berbasis manual masih ada kekurangan dalam pemilihan soal test, penilaian dan penjadwalan test. Dilakukan evaluasi terhadap hal-hal tersebut di atas, diperoleh kesimpulan perlu tindak lanjut dalam hal efisiensi pelaksanaan komprehensif test dengan merubah pelaksanaan test manual ke test berbasis komputer/teknologi informasi.

Tujuan utama dari penelitian ini adalah mengembangkan tes standar berbasis teknologi informasi untuk ujian komprehensif mahasiswa di Jurusan Pendidikan Geografi dengan menggunakan model pengembangan EDDIE. Selain itu penelitian ini juga bertujuan untuk: (1) Meningkatkan hasil ujian komprehensif mahasiswa di Jurusan Pendidikan Geografi; (2) Mendeskripsikan respon mahasiswa terhadap tes standar berbasis teknologi informasi di Jurusan Pendidikan Geografi.

\section{METODE PENELITIAN \\ Desain Penelitian}

Penelitian ini didesain dalam bentuk penelitian penelitian pengembangan (research and development) dimana populasi dalam penelitian ini ialah seluruh mahasiswa yang 
telah mengambil 135 SKS di Jurusan Pendidikan Geografi FIS Universitas Negeri Medan. Indikator penilaian kelayakan soal tes standar berupa kelayakan isi/materi dan kelayakan bahasa.

\section{Rancangan Penelitian}

Pelaksanaan penelitian selama 6 bulan, dari bulan Juli - Oktober 2017. Penelitian $R \& D$ ini menggunakan model ADDIE (Benny A. Pribadi, 2009). Tahapan Model pengembangan ADDIE terdiri dari Analysis, Desain, Development, Implementatiom, dan Evaluation.

Tahap pertama adalah Analysis. Tahap analisis dilakukan untuk mengumpulkan berbagai informasi sebagai bahan perencanaan produk yang akan dikembangkan dengan melibatkan dosen dan mahasiswa di Jurusan Pendidikan Geografi FIS Unimed. Tahap analisis meliputi analisis kurikulum dan analisis kebutuhan yang akan membantu dalam mengetahui kendala dan kebutuhan mahasiswa dalam pelaksanaan tes standar berbasis teknologi informasi.

Tahap kedua dari model pengembangan ADDIE adalah tahap design atau perencanaan. Pada tahap ini mulai dirancang tes standar yang akan dikembangkan sesuai hasil analisis yang dilakukan pada tahap sebelumnya. Instrumen penilaian tes standar dikembangkan untuk menilai kelayakan soal, respon siswa dan efektifitas tes standar. Instrumen penilaian untuk mengetahui kelayakan soal dan responmahasiswa menggunakan kuisioner. Sedangkan instrumen penilaian untuk mengetahui efektifitas tes standar menggunakan instrumen penilaian berupa soal tes yang akan diberikan kepada siswa sebelum dan setelah menggunakan tes standar.Tahap ketiga adalah development (pengembangan). Pada tahap pengembangan dilakukan penulisan draft tes standar dan validasi produk. validasi produk dilakukan untuk menilai kelayakan soal melalui beberapa tahapan yaitu: (1) validasi isi/materi sesuai dengan capaian pembelajaran yang dituntut dalam matakuliah Evaluasi Hasil Belajar, dan (2) validasi bahasa.

Tahap keempat dalam model pengembangan ADDIE adalah implementation (implementasi). Implementasi dilakukan di Jurusan Pendidikan Geografi kepada 10 sampel yang diambil secara random dari mahasiswa yang telah menyelesaikan minimal 135 SKS. Setelah itu, dilakukan tes untuk mengukur efektifitas penggunaan teknologi informasi dalam tes komprehensif. Kemudian, untuk mengetahui respon mahasiswa dilakukan dengan mengisi kuisioner. Selanjutnya, tahap kelima adalah evaluation(evaluasi). Evaluasi merupakan proses yang dilakukan untuk memberikan nilai terhadap tes standar berbasis teknologi informasi.

\section{Teknik Analisis Data}

Kelayakan naskah soal yang digunakan dalam tes standar berbasis $\mathrm{TI}$ meliputi kelayakan isi/materi dan kelayakan bahasa. kelayakan isi atau materi ini meliputi kesesuaian dan kemutakhiran soal sesuai dengan kurikulum yang telah dirancang pada masing-masing KDBK. sedangkan kelayakan bahasa diukur dengan validasi bahasa yang digunakan sesuai dengan kriteria penulisan soal pilihan ganda yang benar. Aspek yang menjadi fokus penelitian kelayakan naskah soal secara garis besar adalah dari segi materi, konstruksi, dan bahasa/budaya.

Persepsi mahasiswa terhadap penggunaan tes standar berbasis teknologi informasi ini dilakukan dengan menggunakan angket dengan skala likert. Angket diberikan kepada siswa setelah melaksanakan tes kepada 10 mahasiswa. Aspek yang dinilai untuk mengukur persepsi mahasiswa secara garis besar adalah dari aspek tampilan, aspek kemanfaatan, aspek materi. Respon mahasiswa kemudian dihitung dengan menggunakan formula :

persentase skor

$$
=\frac{\sum \text { skor perolehan }}{\sum \text { skor maksimum }}
$$


(sugiyono, 2012)

Tabel 1. Kategori Respon Mahasiswa Terhadap Video Tutorial

\begin{tabular}{|c|c|}
\hline Rata - Rata Persentase Skor & Kategori \\
\hline$\leq 10$ & Sangat Buruk \\
\hline $10-13$ & Buruk \\
\hline $14-17$ & Cukup \\
\hline $18-21$ & Baik \\
\hline$\geq 22$ & Sangat Baik \\
\hline
\end{tabular}

\section{HASIL DAN PEMBAHASAN}

\section{Kelayakan Soal Tes Standar}

Ujian komprehensif merupakan ujian yang dilaksanakan secara berkala di setiap jurusan maupun program studi untuk mengukur dan menilai kompetensi setiap mahasiswa yang telah mengikuti proses perkuliahan sebanyak 135 SKS atau lebih kurang 3 tahun 6 bulan. Khusus untuk Jurusan Pendidikan Geografi menggunakan ujian komprehensif sebagai salah satu tolak ukur untuk mengetahui mutu pendidikan di lingkungan Jurusan. Oleh karena itu, mahasiswa yang mendapatkan lulus pada ujian komprehensif saja yang diperbolehkan mengikuti sidang meja hijau.

Sebelum pelaksanaan ujian komprehensif, perlu ditinjau terlebih dahulu instrumen soal tes standar ujian tersebut yang terdiri dari butir soal pada masing-masing KDBK yang akan diujikan. Sejauh ini, institusi belum pernah melakukan pengujian terhadap tes standar yang digunakan dalam ujian komprehensif secara kongkret. Oleh karena itu, perlu adanya penelitian yang membahas tentang kelayakan tes standar ujian komprehensif ini. Pengujian ini dilakukan untuk menilai kelayakan soal tes standar yang digunakan dalam ujian komprehensif.

Kelayakan (validitas) soal tes standar pada ujian komprehensif dinilai dari aspek isi (materi), bahasa, dan konstruksi. Validitas isi (materi) adalah validitas yang dilihat dari segi isi sebagai alat pengukur hasil belajar (Sudijono, 2006: 164). Validitas isi sering pula dinamakan validitas kurikulum yang berarti bahwa suatu alat ukur dapat dikatakan valid apabila sesuai dengan isi kurikulum yang akan diukur (Surapranata, 2005: 51). Menurut Djiwandono (1996: 92), validitas isi menuntut adanya kesesuaian isi antara kemampuan yang ingin diukur dan tes yang digunakan untuk mengukurnya. Cara untuk mengkaji validitas isi adalah dengan pendekatan rasional, yaitu membandingkan antara soal dengan kisikisi soal atau kurikulum yang telah diajarkan (Thoha, 2003: 112).

Aspek bahasa yang diukur antara lain penggunaan bahasa indonesia yang benar dan komunikatif, tidak menggunakan bahasa ibu, serta tidak terjadi pengulangan kata yang tidak perlu. Ketepatan konstruksi penyusunan soal piliha ganda menuntut kesesuaian konstruksi soal dengan konstruksi butir tes. Aspek konstruksi meliputi kejelasan pokok soal yang dirumuskan, efisiensi kalimat dalam instruksi maupun jawaban soal, pilihan jawaban tidak bersifat negatif, tidak menggunakan pilihan jawaban semua benar maupun semua salah, pengurutan angka dari terkecil ke yang terbesar pada pilihan jawaban, serta butir soal tidak terikat pada butir soal yang lain.

Terdapat 400 item soal yang terdiri dari 100 item soal teknik, 100 item soal pendidikan, 100 item soal fisik dan lingkungan serta 100 item soal sosial dan humaniora. 400 item soal ini disusun oleh delapan (8) dosen pengampu matakuliah di Jurusan Pendidikan Geografi yang terdiri dari 2 dosen pada masing-masing konsentrasi. Dari 400 item soal tersebut kemudian diacak dan dijadikan empat paket soal yaitu paket A, B, C, dan D.

Dari 400 item soal yang telah disusun, 77 soal tergolong soal yang tidak 
valid seperti yang tergambar pada tabel berikut:

Tabel 2. Persentase Item Valid Dan Invalid Dalam Naskah Soal Tes Standar

\begin{tabular}{|c|c|c|}
\hline KRITERIA & $F$ & PERSENTASE \\
\hline valid & 323 & 80,75 \\
\hline tidak valid & 77 & 19,25 \\
\hline TOTAL & 400 & 100 \\
\hline
\end{tabular}

Sumber : pengolahan data penelitian, 2017

Berdasarkan persentasenya, sebesar $80,75 \%$ item soal tergolong valid dilihat dari aspek materi (isi), konstruksi soal, dan bahasa yang digunakan dalam kalimat soal maupun pilihan jawaban. Dari persentase tersebut dapat disimpulkan bahwa sebanyak 323 item soal sudah layak digunakan dalam tes standar. Namun, $19,25 \%$ item soal tergolong invalid, ini artinya sebanyak 77 item soal yang tersebar di bidang teknik, pendidikan, fisik dan lingkungan, dan sosial, tidak layak untuk digunakan serta perlu perbaikan sebelum digunakan dalam tes standar ujian komprehensif di Jurusan Pendidikan Geografi. Lebih lanjut perbandingan persentase soal yang layak dan belum layak digunakan dapat dilihat pada diagram berikut ini:

\section{Analisis Soal Tes Standar KDBK Teknik}

Kelompok dosen bidang keahlian (KDBK) teknik terdiri dari beberapa matakuliah wajib maupun pilihan di
Jurusan Pendidikan Geografi. Matakuliah tersebut diantaranya Kartografi, Praktikum Kartografi, Survei Pemetaan, Sistem Informasi Geografi (SIG), Penginderaan Jauh, Analisis dan Interpretasi Citra Digital, dan Analisis dan Interpetasi Peta. Dari 7 matakuliah tersebut, hanya Matakuliah Interpretasi Citra Digital dan Matakuliah Analisis dan Interpretasi Peta yang termasuk matakuliah pilihan. Selebihnya, 5 Matakuliah lain termasuk pada Matakuliah wajib di Jurusan Pendidikan Geografi.

Dua dosen KDBK teknik menyusun 100 soal pilihan ganda yang mencakup keseluruhan capaian pembelajaran pada ketujuh Matakuliah pada KDBK Teknik diatas. seluruh soal tersebut dianalisa kelayakan soalnya dan didapat bahwa dari 100 soal, 26 soal tergolong tidak valid, artinya 26 soal tersebut perlu diperbaiki kembali agar layak digunakan dalam tes standar pada ujian komprehensif di Jurusan Pendidikan Geografi. Lebih jelas dapat dilihat pada tabel 3.

Tabel 3. Persentase Item Valid Dan Invalid Dalam Naskah Soal Tes Standar KDBK Teknik

\begin{tabular}{|c|c|c|}
\hline KRITERIA & $F$ & PERSENTASE \\
\hline Valid & 74 & 74 \\
\hline tidak valid & 26 & 26 \\
\hline TOTAL & 100 & 100 \\
\hline
\end{tabular}

Sumber : pengolahan data penelitian, 2017

Jika dilihat perbandingan persentasenya, maka $26 \%$ soal tes standar pada KDBK teknik tergolong belum valid dan $74 \%$ lainnya sudah layak untuk digunakan. Analisa lebih lanjut menunjukkan bahwa dari 26 soal yang belum layak digunakan, sebagian besar bermasalah dari aspek bahasa yaitu sebanyak16 soal atau sebesar $61,54 \%$ dari seluruh soal yang tidak valid pada KDBK Teknik. Selanjutnya, dari aspek konstruksi sebanyak 7 soal atau sebesar $26,92 \%$ dari total soal invalid, dan dari aspek materi sebanyak 3 soal atau 11,54 \%. 
Persentase soal invalid atau belum layak digunakan berdasarkan aspek materi, konstruksi dan bahasa dapat dilihat pada tabel 4 berikut ini.

Tabel 4. Persentase Soal Invalid Pada Setiap Aspek di Bidang Teknik

\begin{tabular}{|l|c|c|}
\hline \multicolumn{1}{|c|}{ ASPEK } & ¿ SOAL INVALID & PERSENTASE \\
\hline Materi & 3 & 11,54 \\
\hline Konstruksi & 7 & 26,92 \\
\hline Bahasa TOTAL & 16 & 61,54 \\
\hline \multicolumn{2}{|c|}{26} & 100 \\
\hline
\end{tabular}

Sumber : pengolahan data penelitian, 2017

Jabaran kelayakan naskah soal pada KDBK teknik berdasarkan masing-masing aspek penilaian antara lain:

\section{a. Aspek materi}

Indikator penilaian validitas soal berdasarkan panduan model penilaian hasil belajar yang dikeluarkan oleh permendikbud tahun 2013 sebanyak 4 indikator seperti yang tergambar pada tabel 6. Dari tabel 7 dibawah ini dapat dianalisa bahwa faktor penyebab ketiga soal tersebut tergolong belum layak dari aspek materi ialah pilihan yang tidak homogen sebanyak dua soal, serta satu soal lainnya dinilai tidak layak karena tidak sesuai dengan indikator.

Tabel 5. Persentase Soal Invalid Dari Aspek Materi

\begin{tabular}{|l|c|c|}
\hline \multicolumn{1}{|c|}{ INDIKATOR } & $\begin{array}{c}\sum \text { SOAL } \\
\text { INVALID }\end{array}$ & PERSENTASE \\
\hline Soal sesuai dengan indikator & 1 & 33,33 \\
\hline $\begin{array}{l}\text { Materi yang ditanyakan sesuai dengan kompetensi (urgensi, } \\
\text { relevasi, kontinyuitas, keterpakaian sehari-hari tinggi) }\end{array}$ & 0 & 0,00 \\
\hline Pilihan jawaban homogen dan logis & 2 & 66,67 \\
\hline Hanya ada satu kunci jawaban & 0 & 0,00 \\
\hline TOTAL & 3 & 100,00 \\
\hline
\end{tabular}

Sumber : pengolahan data penelitian, 2017

\section{b. Aspek konstruksi}

Dari delapan indikator penilaian kelayakan soal untuk aspek konstruksi, hanya dua indikator menjadi penyumbang soal yang tergolong belum layak digunakan. Kedua indikator tersebut yaitu tidak jelasnya pokok soal yang dirumuskan dan pilihan jawaban dalam bentuk angka yang tidak diurutkan berdasarkan besar kecilnya angka atau kronologinya. Dari tujuh (7) soal yang tergolong invalid (belum layak ) digunakan, dua (2) diantaranya disebabkan oleh ketidakjelasan pokok soal yang dirumuskan, dan lima (5) soal lainnya dikarenakan pilihan jawaban dalam bentuk angka yang tidak diurutkan berdasarkan besar kecilnya angka.
Jika dibandingkan dengan seluruh soal yang tidak valid disebabkan oleh konstruksi soal, maka 71, $43 \%$ soal tersebut disebabkan oleh ketidaktelitian penyusun soal dalam mengurutkan pilihan jawaban. Hanya $28,57 \%$ yang disebabkan oleh ketidakefisienan penggunaan kalimat pada pokok soal.

\section{c. Aspek bahasa}

Penilaian kelayakan soal dari aspek bahasa diukur melalui empat indikator yaitu (1). penggunaan Bahasa Indonesia yang benar, (2). tidak menggunakan bahasa ibu, (3). penggunaan bahasa yang komunikatif sehingga mudah dipahami, serta (4). tidak mengulang kata yang sama pada pilihan jawaban. Dari empat 
indikator yang digunakan dalam menilai naskah soal KDBK teknik, ditemukan dua indikator penyumbang invaliditas 16 soal dari segi konstruksi, yaitu (1) penggunaan tanda baca, ejaan dan penulisan kata yang tidak sesuai dengan kaidah Bahasa
Indonesia yang benar sebesar 81, $25 \%$ dari 16 soal atau sebesar 13 soal, dan (2) pengulangan kata yang tidak perlu pada pilihan jawaban sebesar 18,75 \% atau sebanyak 3 soal. Lebih lanjut dapat dilihat pada tabel 6.

Tabel 6. Persentase Soal Invalid Dari Aspek Bahasa

\begin{tabular}{|l|c|c|}
\hline \multicolumn{1}{|c|}{ ASPEK } & $\sum_{\text {INVALID }}$ & PERSENTASE \\
\hline $\begin{array}{l}\text { Menggunakan bahasa yang sesuai dengan kaidah bahasa } \\
\text { Indonesia }\end{array}$ & 13 & 81,25 \\
\hline Menggunakan bahasa yang komunikatif & 0 & 0,00 \\
\hline Tidak menggunakan bahasa yang berlaku setempat/tabu & 0 & 0,00 \\
\hline $\begin{array}{l}\text { Pilihan jawaban tidak mengulang kata/kelompok kata } \\
\text { yang sama, kecuali merupakan satu kesatuan pengertian }\end{array}$ & 3 & 18,75 \\
\hline TOTAL & 16 & 100,00 \\
\hline
\end{tabular}

Sumber : pengolahan data penelitian, 2017

Analisis Soal Tes Standar KDBK Sosial

Kelompok Dosen Bidang Keahlian (KDBK) Sosial terdiri dari tujuh dosen yang mengampu Matakuliah Bidang Keahlian Sosial seperti Matakuliah Geografi Sosial, Geografi Pariwisata, Geografi Ketenagakerjaan, Geografi Penduduk (Demografi), GRI, GRI, GRNB, dan Geografi Desa Kota, dan lain-lain. Dua dari 7 dosen KDBK Sosial ditunjuk untuk menyusun 100 soal sesuai dengan capaian pembelajaran pada masing-masing matakuliah yang termasuk pada KDBK sosial. Dari 100 soal tersebut kemudian dianalisa kelayakannya untuk digunakan dalam tes standar ujian komprehensif di Jurusan Pendidikan Geografi. Untuk beberapa soal yang belum layak kemudian diperbaiki kembali sesuai saran dari validator.

Dari empat naskah soal, Naskah soal bidang KDBK sosial memiliki soal yang invalid paling banyak dibandingkan dengan naskah soal KDBK lainnya. Sebesar $41 \%$ dari 100 soal yang disusun dinyatakan belum layak untuk digunakan. Sisanya sebesar 59 \% tergolong valid atau layak digunakan. Data tersebut dapat dilihat pada tabel 7 berikut.

Tabel 7. Persentase Item Valid Dan Invalid Dalam Naskah Soal Tes Standar KDBK Sosial

\begin{tabular}{|c|c|c|}
\hline KRITERIA & $F$ & PERSENTASE \\
\hline Valid & 59 & 59 \\
\hline tidak valid & 41 & 41 \\
\hline TOTAL & 100 & 100 \\
\hline
\end{tabular}

Sumber : pengolahan data penelitian, 2017

Dari tabel 7 di atas, dapat disimpulkan bahwa $41 \%$ atau 41 dari 100 soal tergolong belum layak digunakan. Dari 41 soal yang tidak valid tersebut dianalisa kembali untuk masing-masing aspek penilaian. Diperoleh hasil bahwa dari aspek bahasa sebesar 56,10 \% atau sebanyak 23 soal KDBK Sosial belum layak digunakan dari aspek bahasa, dari aspek konstruksi sebesar 39,02\% atau sebanyak 16 soal KDBK Sosial belum layak digunakan, dan dari aspek materi (isi) dinyatakan tidak layak sebanyak 2 soal atau sebesar $4,88 \%$. Data tersebut dapat dilihat pada tabel 8 di bawah ini. 
Tabel 8. Persentase Soal Invalid Pada Naskah Soal KDBK Sosial

\begin{tabular}{|c|c|c|}
\hline ASPEK & ¿ SOAL INVALID & PERSENTASE \\
\hline Materi & 2 & 4,88 \\
\hline Konstruksi & 16 & 39,02 \\
\hline Bahasa & 23 & 56,10 \\
\hline TOTAL & 41 & 100 \\
\hline
\end{tabular}

Sumber : pengolahan data penelitian, 2017

Penjabaran hasil lebih lanjut untuk masing-masing aspek penilaian validitas naskah soal dapat dilihat di bawah ini.

\section{a. Aspek Materi}

Aspek materi merupakan salah satu kunci kelayakan soal. Aspek materi ini dilihat dari kesesuaian dengan indikator soal pilihan ganda, relevansi soal dengan indikator dan kompetensi, homogenitas jawaban serta kepastian satu kunci jawaban. dilihat dari aspek materi ini, hanya dua soal KDBK Sosial yang belum layak digunakan. Kedua soal tersebut dinyatakan belum layak karena ketidakcocokan soal untuk pilihan ganda. Pada pokok soal masih dituliskan kata tanya yang sebenarnya lebih cocok digunakan untuk soal berbentuk uraian atau esay, bukan pilihan ganda. Kedua soal tersebut bisa terkategori layak jika kalimat pada pokok soal diganti kembali. Data tersebut dapat dilihat pada tabel 9 berikut.

Tabel 9. Persentase Soal Invalid Dari Aspek Materi

\begin{tabular}{|l|c|c|}
\hline \multicolumn{1}{|c|}{ INDIKATOR } & $\begin{array}{c}\text { ISOAL } \\
\text { INVALID }\end{array}$ & $\begin{array}{c}\text { PERSEN } \\
\text { TASE }\end{array}$ \\
\hline Soal tidak sesuai dengan indikator dan untuk pilihan ganda & 2 & 100,00 \\
\hline $\begin{array}{l}\text { Materi yang ditanyakan sesuai dengan kompetensi (urgensi, relevasi, } \\
\text { kontinyuitas, keterpakaian sehari-hari tinggi) }\end{array}$ & 0 & 0,00 \\
\hline Pilihan jawaban homogen dan logis & 0 & 0,00 \\
\hline Hanya ada satu kunci jawaban & 0 & 0,00 \\
\hline TOTAL & 2 & 100 \\
\hline
\end{tabular}

Sumber : pengolahan data penelitian, 2017

\section{b. Aspek Konstruksi}

Penilaian kelayakan soal dilihat dari aspek konstruksi soal menunjukan bahwa sebanyak 16 soal dari naskah soal KDBK Sosial terkategori belum layak digunakan. Analisa lebih lanjut menunjukan bahwa 8 soal atau $50 \%$ dari 16 soal tersebut dinyatakan belum layak digunakan karena menggunakan pilihan jawaban "semua jawaban di atas benar/salah". 4 atau sebesar $25 \%$ dari 16 soal tidak mengurutkan pilihan jawaban dalam bentuk angka berdasarkan besar kecilnya, 3 soal atau sebesar 18,75 \% dikarenakan panjang pilihan jawabannya tidak sama, dan 1 soal atau sebesar $6,25 \%$ karena ketidakjelasan pokok soal yang dirumuskan penyusun soal. Seluruh soal tersebut dilakukan perbaikan kembali sesuai dengan indikator yang dituntut pada aspek konstruksi sehingga akhirnya soal tersebut layak digunakan untuk tes standar di Jurusan Pendidikan Geografi.

\section{c. Aspek Bahasa}

Dari aspek bahasa, 22 dari 100 soal KDBK Sosial dinyatakan tidak valid atau tidak layak digunakan. Satu-satunya penyebab ketidaklayakan 22 soal ini adalah penggunaan kaidah bahasa indonesia yang tidak tepat. Beberapa hal diantaranya ialah penggunaan istilah asing 
yang tidak dimiringkan, dan kesalahan penggunaan tanda baca. Walaupun kesalahan tersebut tidak mengubah makna soal, tetapi tetap dilakukan perbaikan sehingga diharapkan kualitas soal menjadi lebih baik.

Analisis Soal Tes Standar KDBK Pendidikan

Tabel 10. Persentase Soal Valid Dan Invalid Pada Naskah Soal KDBK Pendidikan

\begin{tabular}{|c|c|c|}
\hline KRITERIA & $F$ & PERSENTASE \\
\hline Valid & 88 & 88 \\
\hline tidak valid & 12 & 12 \\
\hline TOTAL & 100 & 100 \\
\hline
\end{tabular}

Sumber : pengolahan data penelitian, 2017

Keseluruhan soal yang tidak valid pada KDBK pendidikan dikarenakan kurang baiknya penyusunan soal dari aspek

Tabel 11. Persentase Soal Invalid Pada Setiap Aspek

\begin{tabular}{|c|c|c|}
\hline Aspek & $\sum$ Soal Invalid & Persentase \\
\hline Materi & 0 & 0,00 \\
\hline Konstruksi & 0 & 0,00 \\
\hline Bahasa & 12 & 100,00 \\
\hline Total & 12 & 100 \\
\hline
\end{tabular}

Sumber : pengolahan data penelitian, 2017

Hasil analisa lebih lanjut menunjukan bahwa 12 soal yang belum layak digunakan pada naskah soal KDBK Pendidikan disebabkan kurang berhati hatinya menuliskan soal, sehingga beberapa pokok soal ditulis tidak sesuai dengan bahasa Indonesia yang benar, seperti penggunaan huruf kapital dan penggunakan kata miring untuk bahasa asing. Selain itu tidak lagi ditemukan kesalahan lainnya.

\section{Analisis Soal Tes Standar KDBK Fisik Dan Lingkungan}

Kelompok dosen bidang keahlian (KDBK) fisik dan lingkungan merupakan salah satu KDBK di Jurusan Pendidikan Geografi yang terdiri dari Matakuliah Hidrologi, Meteorologi \& Klimatologi, Geologi, Geomorfologi, Dan Geologi Dan Meteorologi Indonesia, IPA Dasar, Ekologi, dan lain-lain. Dari 100 soal yang disusun untuk naskah soal KDBK Fisik dan Lingkungan, $20 \%$ tergolong belum layak digunakan. Hal ini dapat dilihat pada tabel 12 berikut.

Tabel 12. Persentase Soal Valid Dan Invalid Pada Naskah Soal KDBK Fisik dan Lingkungan

\begin{tabular}{|l|c|c|}
\hline \multicolumn{1}{|c|}{ kriteria } & $F$ & persentase \\
\hline valid & 80 & 80 \\
\hline tidak valid & 20 & 20 \\
\hline TOTAL & 100 & 100 \\
\hline
\end{tabular}

Sumber: Hasil Penelitian, 2017 
15 soal atau sebesar $75 \%$ dari 20 soal yang belum layak digunakan ternyata terkendala pada aspek bahasa, sedangkan
$25 \%$ atau 5 soal terkendala pada aspek konstruksi soal. Seperti yang tergambar pada tabel 13 berikut.

Tabel 13. Persentase Soal Invalid Pada Setiap Aspek

\begin{tabular}{|c|c|c|}
\hline Aspek & $\sum$ Soal Invalid & Persentase \\
\hline Materi & 0 & 0,00 \\
\hline Konstruksi & 5 & 25,00 \\
\hline Bahasa & 15 & 75,00 \\
\hline TOTAL & 20 & 100 \\
\hline
\end{tabular}

Sumber: Hasil Penelitian, 2017

Dua kendala yang disebutkan diatas dapat dilihat pada jabaran berikut ini:

Aspek Konstuksi

Lima soal yang tergolong invalid dari aspek konstruksi disebabkan oleh ketidakjelasan pokok soal yang dirumuskan pada satu soal, pokok soal tidak memberi petunjuk kunci jawaban pada dua soal, dan dua soal lagi dikarenakan menggunakan pilihan jawaban " semua jawaban benar".

\section{Aspek Bahasa}

Sebagian besar item soal pada naskah soal KDBK Fisik dan Lingkungan yang tergolong belum layak digunakan disebabkan oleh faktor bahasa. Kesalahan umum yang terjadi pada setiap naskah soal ialah kesalaahan penggunaan kaidah Bahasa Indonesia yang benar. Pada naskah soal KDBK Fisik dan Lingkungan ditemukan 15 soal yang tidak layak digunakan karena faktor ini.
Tanggapan responden terhadap kuesioner yang diberikan peneliti nampak pada jawaban responden. Dalam analisis ini akan diuraikan mengenai kecenderungan pendapat dan tanggapan dari mahasiswa Jurusan Pendidikan Geografi FIS Unimed yang telah mengikuti 135 SKS. Pernyataan-pernyataan responden mengenai variabel penelitian dapat dilihat pada jawaban responden terhadap kuesioner yang diberikan peneliti dan pernyataan ini membentuk skala likert, dimana skala likert ini dapat digunakan untuk mengukur sikap responden.

Setelah semua indikator respon didapatkan, kemudian penilaian tanggapan penggunaan aplikasi tes standar untuk ujian komprehensif dalam hal ini mahasiswa yang telah mengambil dan lulus sebanyak 135 SKS kemudian disederhanakan dan disimpulkan. Hasil tanggapan mahasiswa tersebut dapat dilihat pada tabel 14 berikut.

\section{Respon Mahasiswa Berkenaan Tes Standar Berbasis Teknologi Informasi}

Tabel 14. Deskripsi Tanggapan Mahasiswa Terhadap Indikator Utama Penggunaan Aplikasi

Tes Standar

\begin{tabular}{|c|l|c|c|c|c|c|}
\hline \multirow{2}{*}{ Nomor } & \multirow{2}{*}{ Pernyataan } & \multicolumn{5}{|c|}{ Persentase (\%) } \\
\cline { 3 - 7 } & Aspek Tampilan & STS & TS & N & S & SS \\
\hline 1 & Aspek Pengoperasian & $1.25 \%$ & $5.00 \%$ & $10.00 \%$ & $22.50 \%$ & $61.25 \%$ \\
\hline 2 & Aspek Kemanfaatan & $0.00 \%$ & $0.00 \%$ & $0.00 \%$ & $6.25 \%$ & $93.75 \%$ \\
\hline 3 & Aspek Materi & $1.00 \%$ & $6.00 \%$ & $24.00 \%$ & $29.00 \%$ & $40.00 \%$ \\
\hline 4 & Rata-rata & $0.56 \%$ & $2.91 \%$ & $12.09 \%$ & $24.28 \%$ & $60.16 \%$ \\
\hline
\end{tabular}


Sumber: Hasil Penelitian, 2017

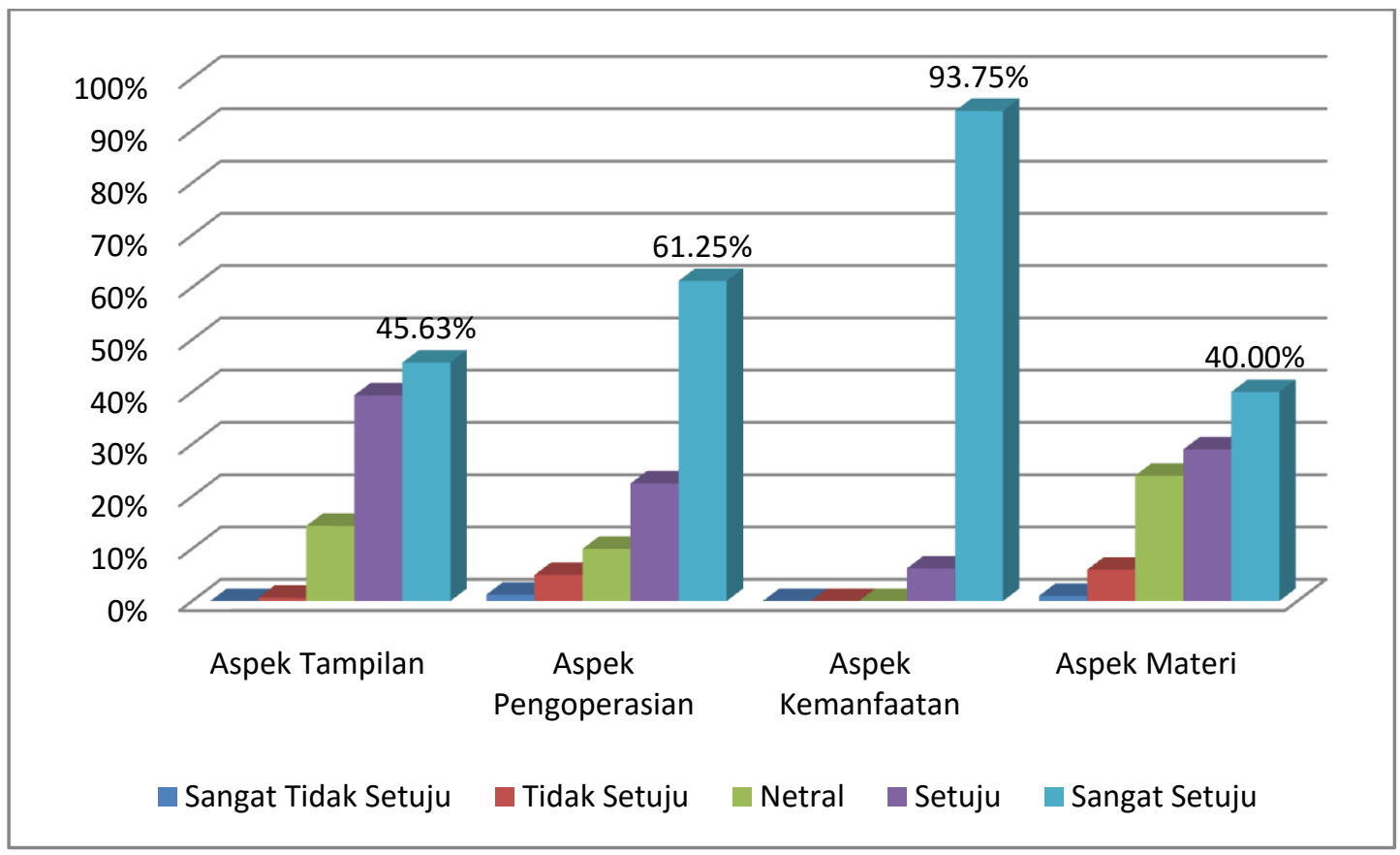

Gambar 1. Tanggapan Mengenai Indikator Utama Penggunaan Aplikasi Tes Standar

Berdasarkan Tabel 14 dan Gambar 1 di atas menunjukan bahwa sebanyak 45,63 \% mahasiswa menyatakan sangat setuju dan $39,38 \%$ menyatakan setuju mengenai persepsi kelayakan aspek tampilan aplikasi. Dalam hal aspek pengoperasian, sebanyak $61,25 \%$ menyatakan sangat setuju dan $22,5 \%$ menyatakan setuju. Dalam hal aspek kemanfaatan aplikasi tes standar, mahasiswa menyatakan 93,75 \%sangat setuju bahwa aplikasi ini sangat bermanfaat untuk mahasiwa, serta $40 \%$ mahasiswa menyatakan sangat setuju pada kelayakan materi pada aplikasi tes standar.

Respon mahasiswa diperlukan sebagai bagian dari evaluasi terhadap penerapan tes standar pada ujian komprehensif di Jurusan Pendidikan
Geografi FIS Unimed. Respon mahasiswa diukur dengan menggunakan angket berskala rentangan $1-5$. Persentase total skor diperoleh dengan menggunakan rumus :

jumlah skor $=$ (jumlah skor perolehan /jumlah skor maksimum) * $100 \%$

Jumlah skor perolehan didapat dari hasil kuesioner mengenai tanggapan penggunaan aplikasi tes standar oleh mahasiswa yang sudah diberi pembobotan sesuai dengan kelas, sedangkan jumlah skor maksimum merupakan total perolehan paling tinggi yang berada pada kelas respon Sangat Setuju. Besar skor masingmasing kelas respon dapat dilihat pada Tabel 15 berikut.

Tabel 15. Kelas Respon Mahasiswa Terhadap Penggunaan Aplikasi Tes Standar

\begin{tabular}{|c|l|c|c|c|c|c|}
\hline \multirow{2}{*}{ No } & \multicolumn{2}{|c|}{ Indikator } & \multicolumn{5}{|c|}{ Kelas Respon } \\
\cline { 3 - 7 } & & $\begin{array}{c}\text { Sangat } \\
\text { Buruk }\end{array}$ & Buruk & Sedang & Baik & $\begin{array}{c}\text { Sangat } \\
\text { Baik }\end{array}$ \\
\hline 1 & Aspek Tampilan & $<14$ & $14-20$ & $21-27$ & $28-34$ & $>34$ \\
\hline 2 & Aspek Pengoperasian & $<8$ & $8-10$ & $11-13$ & $14-16$ & $>16$ \\
\hline 3 & Aspek Kemanfaatan & $<8$ & $8-10$ & $11-13$ & $14-16$ & $>16$ \\
\hline
\end{tabular}




\begin{tabular}{|l|l|l|l|l|l|l|}
4 & Aspek Materi & $<9$ & $9-12$ & $13-16$ & $17-20$ & $>20$ \\
\hline
\end{tabular}

Sumber: Hasil Penelitian, 2017

Kelas respon didapat dari rentang skor masing-masing indikator respon yang merupakan hasil selisih skor maksimum yang bisa didapat dengan skor minimum yang kemudian dibagi kedalam lima kelas respon, yaitu Sangat Buruk, Buruk, Sedang, Baik, dan Sangat Baik. Hasil respon mahasiswamengenai aplikasi tes standar pada ujian komprehensif dapat dilihat pada tabel 16 dan gambar 2 berikut.

Tabel 16. Respon Mahasiswa Terhadap Penggunaan Tes Standar

\begin{tabular}{|c|c|c|c|c|c|}
\hline No. & Pernyataan & $\begin{array}{l}\text { Skor yang } \\
\text { diperoleh }\end{array}$ & $\begin{array}{l}\text { Kategori } \\
\text { Respon }\end{array}$ & Persentase & $\begin{array}{c}\text { Respon } \\
\text { Secara } \\
\text { Umum }\end{array}$ \\
\hline 1 & Aspek Tampilan & 34.4 & Sangat Baik & $86.00 \%$ & \multirow{4}{*}{$\begin{array}{c}\text { Sangat } \\
\text { Baik }\end{array}$} \\
\hline 2 & Aspek Pengoperasian & 17.5 & Sangat Baik & $87.50 \%$ & \\
\hline 3 & Aspek Kemanfaatan & 19.75 & Sangat Baik & $98.75 \%$ & \\
\hline 4 & Aspek Materi & 20.05 & Sangat Baik & $80.20 \%$ & \\
\hline & & \multicolumn{2}{|c|}{ Rata -Rata } & $88.11 \%$ & \\
\hline
\end{tabular}

Sumber: Hasil Penelitian, 2017

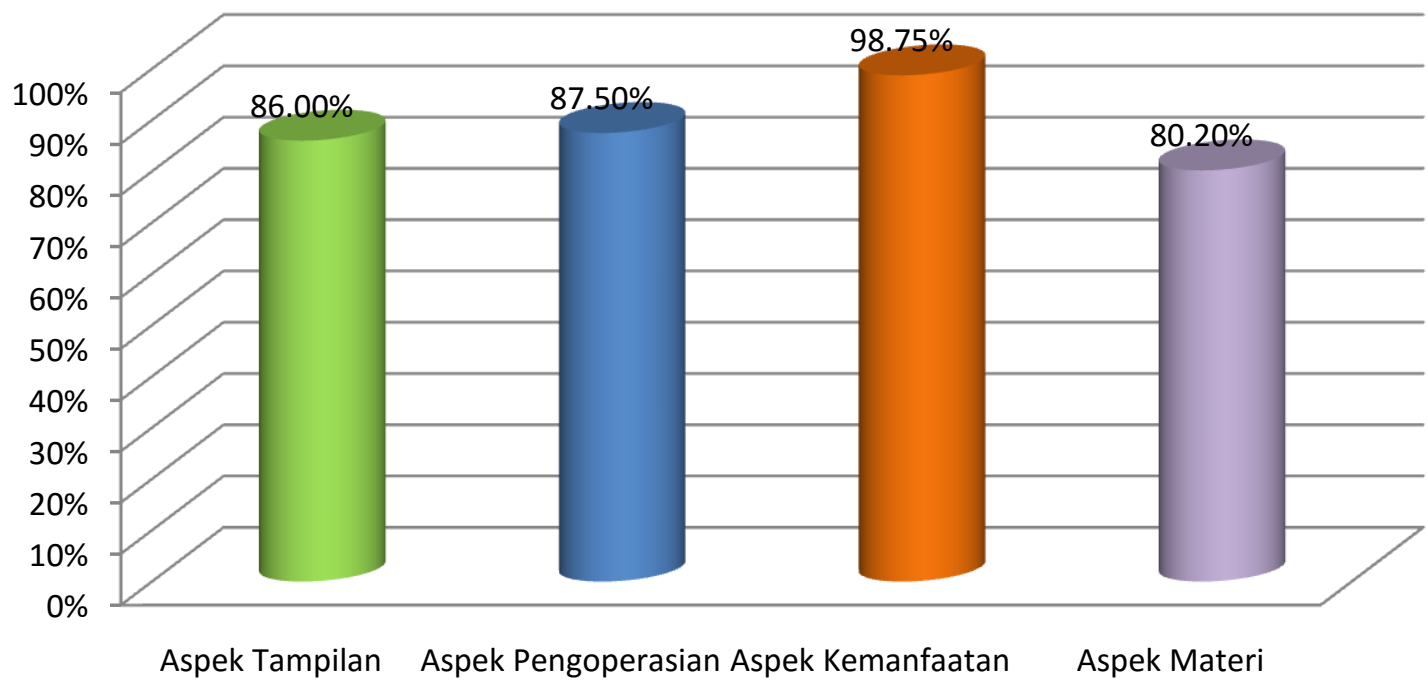

Gambar 12. Respon Mahasiswa Terhadap Penggunaan Tes Standar

Berdasarkan Tabel 15 dan gambar 2 di atas menunjukan bahwa persepsi mengenai tampilan aplikasi mendapatkan skor rata-rata $86 \%$, dalam kemudahan aspek pengoperasian sebesar 87,5 \%, aspek kemanfaatannya sebesar $98,75 \%$ dan aspek kelayakan materi sebesar 80,20 $\%$. Keempat aspek tersebut terkategori sangat baik. Dari keempat indikator penilaian respon mahasiswa mengenai tes standar dapat disimpulkan bahwa secara umum respon mahasiswa terkategori sangat baik. Hal ini didapat dari persentase respon yang menunjukan angka $88,11 \%$. Artinya mahasiswa memberikan tanggapan yang positif mengenai implementasi aplikasi tes standar untuk ujian komprehensif.

\section{KESIMPULAN DAN SARAN Kesimpulan}


1. Hasil penilaian kelayakan tes standar menunjukan bahwa sebesar $80,75 \%$ item soal tergolong valid (layak digunakan) dilihat dari aspek materi (isi), konstruksi soal, dan bahasa yang digunakan dalam kalimat soal maupun pilihan jawaban. Dari persentase tersebut dapat disimpulkan bahwa sebanyak 323 item soal sudah layak digunakan dalam tes standar. Namun, $19,25 \%$ item soal tergolong invalid, ini artinya sebanyak 77 item soal yang tersebar di bidang teknik, pendidikan, fisik dan lingkungan, dan sosial, tidak layak untuk digunakan serta perlu perbaikan sebelum digunakan dalam tes standar ujian komprehensif di Jurusan Pendidikan Geografi.

2. Dari indikator tampilan, pengoperasian, kemanfaatan dan materi, penilaian respon mahasiswa mengenai tes standar dapat disimpulkan bahwa secara umum respon mahasiswa terkategori sangat baik. Hal ini didapat dari persentase respon yang menunjukan angka 88,11\%. Artinya mahasiswa memberikan tanggapan yang positif mengenai implementasi aplikasi tes standar untuk ujian komprehensif.

Saran

1. perlu dilakukan pembaharuan secara berkala terhadap soal yang digunakan dalam ujian tes standar di Jurusan Pendidikan Geografi, agar soal yang digunakan dalam ujian komprehensif terjaga kemutakhirannya.

2. Perlu dilakukan uji efektifitas penggunaan aplikasi tes standar untuk ujian komprehensif di Jurusan Pendidikan Geografi guna mengetahui sejauh mana penggunaan aplikasi dalam tes standar ini bermanfaat untuk meningkatkan hasil tes komprehensif

\section{DAFTAR PUSTAKA}

Abdulhak, H. I. \& Sanjaya, W. (2005). Media Pendidikan: Suatu Pengantar. Bandung: Pusat Pelayanan dan Pengembangan Media Pendidikan UPI Bandung.

Arikunto, Suharsimi. (2003).Dasar-Dasar Evaluasi Pendidikan. Jakarta: Bumi Aksara.

Azwar, Syaifuddin. (1997). Reliabilitas dan Validitas (edisi 3). Yogyakarta: Pustaka Pelajar Offset.

Bambang Warsita. (2008). Teknologi Pembelajaran, landasan dan aplikasinya. Jakarta: Rineka Cipta.

Hamid, M.A. (2016). Pengembangan Instrumen Hasil Belajar Siswa Berbasis TIK Pada Pembelajaran Dasar Listrik Elektronika. VOLT: Jurnal Ilmiah Pendidikan Teknik Elektro. 1(1), 37-46.

Jamal Ma'mur Asmani. (2011). Tips Efektif Pemanfaatan Teknologi Informasi dan Komunikasi Dalam Dunia Pendidikan. Yogyakarta: Diva Press.

Jimoh, R. G., Shittu, A.J.K \& Kawu, Y. K. (2012). Students' Perception of Computer Based Test (CBT) for Examining Undergraduate Chemistry Courses. Journal of Emerging Trends in Computing and Information Sciences, 3: 125-134.

Mukhtar. (2011). Desain Pembelajaran Berbasis Teknologi Informasi Dan Komunikasi(Sebuah Orientasi Baru). Jakarta: Gaung Persada Press.

Munir. (2009). Pembelajaran Jarak Jauh Berbasis Teknologi Informasi dan Komunikasi. Bandung: Alfabeta. 
Munir. (2012). Multimedia konsep dan aplikasi dalam pendidikan.

Bandung: Alfabeta.

Prasojo Diat Lantip, Riyanto,. (2011).Teknologi Informasi Pendidikan Yogyakarta : Gava Media.

Purwanto, Ngalim. (2006). Prinsip-Prinsip Dan Teknik Evaluasi Pengajaran. Bandung: PT. Remaja Rosdakarya.

Sudijono, A. (2015). Pengantar Evaluasi Pendidikan. PT Radja Grafindo Persada. Jakarta.

Sudjana, Nana. (2014). Penilaian Hasil Proses Belajar Mengajar. PT Remaja Rosdakarya. Bandung.

Sudar, Yulianto, A., \& Wiyanto. (2014). PENGEMBANGAN UJI KOMPETENSI MANDIRI BERBASIS KOMPUTER UNTUK MENINGKATKAN EFIKASI DIRI SISWA. Jurnal Pendidikan Fisika Indonesia, 10, 9-14.

Suyanto, M. (2005). Pengantar Teknologi untuk Bisnis. Yogyakarta: Andi Offset.

Toha, Chabib. (2003). Teknik Evaluasi Pendidikan. Jakarta: PT. Raja Grafindo Persada.

Uno, B., Hamzah, Lamatenggo, Nina. (2011). Teknologi Komunikasi dan Informasi Pembelajaran. Bumi Aksara. Jakarta. 